Case Report

\title{
Two Cases of the MYH9 Disorder Fechtner Syndrome Diagnosed from Observation of Peripheral Blood Cells before End-Stage Renal Failure
}

\author{
Shin Teshirogi, ${ }^{1}$ Jun Muratsu $\mathbb{D}^{1},{ }^{1}$ Hidenori Kasahara, ${ }^{1}$ Ken Terashima, ${ }^{1}$ Sho Miki, \\ Tomohiro Minami, ${ }^{1}$ Yujiro Okute, ${ }^{1}$ Suguru Yoneda, ${ }^{1}$ Atsuyuki Morishima ${ }^{\mathbb{D}},{ }^{1}$ \\ Shinji Kunishima, ${ }^{2}$ and Katsuhiko Sakaguchi $\mathbb{D}^{1}$ \\ ${ }^{1}$ Department of Nephrology and Hypertension, Sumitomo Hospital, 5-3-20 Nakanoshima, Kita-ku, Osaka 530-0005, Japan \\ ${ }^{2}$ Department of Advanced Diagnosis, Clinical Research Center, National Hospital Organization Nagoya Medical Center, \\ Nagoya, Japan \\ Correspondence should be addressed to Jun Muratsu; jm27252725@yahoo.co.jp
}

Received 22 June 2019; Revised 21 August 2019; Accepted 4 October 2019; Published 26 November 2019

Academic Editor: Yoshihide Fujigaki

Copyright (C) 2019 Shin Teshirogi et al. This is an open access article distributed under the Creative Commons Attribution License, which permits unrestricted use, distribution, and reproduction in any medium, provided the original work is properly cited.

\begin{abstract}
As a MYH9 disorder, Fechtner syndrome is characterized by nephritis, giant platelets, granulocyte inclusion bodies (Döhle-like bodies), cataract, and sensorineural deafness. Observation of peripheral blood smear for the presence of thrombocytopenia, giant platelets, and granulocyte inclusion bodies (Döhle-like bodies) is highly important for the early diagnosis of $M Y H 9$ disorders. In our two cases, sequencing analysis of the $\mathrm{MYH9}$ gene indicated mutations in exon 24 . Both cases were diagnosed as the MYH9 disorders Fechtner syndrome before end-stage renal failure on the basis of the observation of peripheral blood smear.
\end{abstract}

\section{Introduction}

MYH9 mutations cause the autosomal dominant macrothrombocytopenic syndrome of May-Hegglin anomaly, Fechtner syndrome, Sebastian syndrome, and Epstein syndrome. Recently, these diseases are being referred to as $\mathrm{MYH9}$ disorders. The MYH9 gene encodes the nonmuscle myosin heavy chain -IIA (NMMHC-IIA). MYH9 disorders are characterized by giant platelets, thrombocytopenia, and characteristic Döhle-like bodies in granulocytes. Among these diseases, the involvement of Alport syndrome symptoms, namely nephritis, cataract, and sensorineural deafness, is associated with the mutation site of the MYH9 gene. Fechtner syndrome, a MYH9 disorder, develops nephritis and end-stage renal failure. In most previous reports of MYH9 disorders in Japan, Fechtner syndrome was diagnosed after end-stage renal failure. Here, our two cases were diagnosed before end-stage renal failure on the basis of the observation of peripheral blood smear, neutrophil inclusion bodies (Döhle-like bodies), and giant platelets.
In the management of chronic kidney disease, the findings from peripheral blood smear, presence of the Döhle-like bodies in neutrophils, and giant platelets are important for the early diagnosis of $M Y H 9$ disorders, especially if the symptoms are not evident.

\section{Case Presentation}

2.1. Case 1. A 56-year-old male was referred to our hospital for the management of chronic kidney disease. At the age of 17 years, hematuria and proteinuria were observed. At the age of 30 years, he presented with thrombocytopenia, sensorineural deafness, and cataract. At the age of 56 years, he was referred to our hospital for the management of hypertension and elevated serum creatinine level. His blood and urinary analysis results are shown in Table 1. In the peripheral blood smear, thrombocytopenia, giant platelets, and neutrophil inclusion bodies (Döhle-like bodies) were observed with May-Giemsa staining (Figure 1). We identified a relevant family history 
TABLE 1: Clinical characteristics, blood and urinary analysis of these cases.

\begin{tabular}{|c|c|c|c|}
\hline & Case 1 & Case 2 & Reference range \\
\hline Height $(\mathrm{cm})$ & 173 & 164 & \\
\hline Weight (kg) & 79.2 & 64.1 & \\
\hline $\operatorname{BMI}\left(\mathrm{kg} / \mathrm{m}^{2}\right)$ & 26.5 & 23.8 & \\
\hline \multicolumn{4}{|l|}{ Urinary analysis } \\
\hline $\mathrm{pH}$ & 6.0 & 5.0 & $5.0-7.5$ \\
\hline Specific gravity & 1.003 & 1.019 & $1.005-1.030$ \\
\hline Protein (g/day) & 1.5 & 0.02 & negative \\
\hline Urine occult blood reaction Cast & $\begin{array}{l}\text { 1+ fatty cast, epithelial cast and } \\
\text { granular cast }\end{array}$ & $\begin{array}{c}\text { Negative hyaline cast, epithelial cast } \\
\text { and granular cast }\end{array}$ & Negative negative \\
\hline \multicolumn{4}{|l|}{ Blood analysis } \\
\hline White blood cell $(/ \mu \mathrm{L})$ & 4,300 & 4,000 & $3,300-8,600$ \\
\hline Red blood cell $\left(\times 10^{6} / \mu \mathrm{L}\right)$ & 3.00 & 4.38 & $4.30-5.60$ \\
\hline Hemoglobin (g/dL) & 9.8 & 13.6 & $13.5-17.0$ \\
\hline Hematocrit (\%) & 29.9 & 40.9 & $40.0-51.0$ \\
\hline Platelet counts $\left(\times 10^{4} / \mu \mathrm{L}\right)$ & 8.2 & 8.7 & $15.0-35.0$ \\
\hline Mean platelet volume (fL) & 11.5 & 13.2 & $6.8-9.4$ \\
\hline Bleeding time (minutes) & 1 & 1 & $1-5$ \\
\hline Sodium $(\mathrm{mEq} / \mathrm{L})$ & 141 & 143 & 143 \\
\hline Potassium $(\mathrm{mEq} / \mathrm{L})$ & 4.7 & 4.2 & $3.6-5.0$ \\
\hline Chloride (mEq/L) & 109 & 109 & $98-108$ \\
\hline Calcium (mg/dL) & 8.7 & 8.9 & $8.2-10.2$ \\
\hline Phosphorus (mg/dL) & 6.2 & 2.8 & $2.7-4.4$ \\
\hline Total protein $(\mathrm{g} / \mathrm{dL})$ & 7.0 & 6.4 & $6.7-8.3$ \\
\hline Albumin $(\mathrm{g} / \mathrm{dL})$ & 4.1 & 4.4 & $3.8-5.3$ \\
\hline Blood urea nitrogen (mg/dL) & 78 & 17 & $8-20$ \\
\hline Creatinine $(\mathrm{mg} / \mathrm{dL})$ & 5.91 & 1.24 & $0.36-1.06$ \\
\hline $\begin{array}{l}\text { estimate glomerular filtration rate } \\
(\mathrm{eGFR})\left(\mathrm{mL} / \mathrm{min} / 1.73 \mathrm{~m}^{2}\right)\end{array}$ & 8.8 & 47.6 & \\
\hline Hemoglobin A1c (NGSP) (\%) & 5.7 & 5.3 & $4.6-6.2$ \\
\hline Antinuclear antibody & $\times 40$ & $<\times 40$ & $<\times 40$ \\
\hline
\end{tabular}

(Figure 2(a)). His son had thrombocytopenia. His mother died of subarachnoid hemorrhage at the age of 61 years, and his younger brother had thrombocytopenia and renal dysfunction.

From these findings, we considered the possibility of $\mathrm{MYH} 9$ disorders and performed immunofluorescence analysis for neutrophil NMMHC-IIA localization $[1,2]$. We found a few large NMMHC-IIA aggregates in the neutrophils (Figure 1). Mutational analysis of the $\mathrm{MYH} 9$ gene revealed a heterozygous duplication of 21 nucleotides in exon 24 (p.E1066_A1072dup, c.3195_3215dup; Figure 2(a)).

We started a nutritional therapy and an angiotensin receptor II; antagonist (olemsartan $20 \mathrm{mg} /$ day) to reduce proteinuria.

2.2. Case 2. A 59-year-old male was referred to our hospital because elevated serum creatinine level was indicated in his medical examinations. Renal dysfunction was only recognized at the age of 59 years, when he presented with cataract and sensorineural deafness. In his family history, his father had sensorineural deafness from the age of 20 years and died of cerebral infarction at the age of 84 years. His mother had hypertension from the age of 50 years (Figure 2(b)). Blood and urinary analysis results are shown in Table 1 . In the peripheral blood smear, thrombocytopenia, giant platelets, and neutrophil inclusion bodies (Döhle-like bodies) were observed using MayGiemsa staining (Figure 1). We suspected the possibility of a MYH9 gene abnormality. Immunofluorescence micrographs of neutrophils showed granular accumulation of NMMHC-IIA in the neutrophils (Figure 1). Subsequent genetic mutation analysis revealed p.E1084del mutation (c.3250_3252delGAG) in MYH9 exon 24 (Figure 2(b)). To determine other factors of renal dysfunction, we performed renal biopsy by percutaneous needle aspiration. In the histological analysis, no significant changes were observed in the mesangium and tubulointerstitial lesions on light microscopy. However, on electron microscopy, focal effacement of podocytes and loss of the interpodocyte slit diaphragm were observed (Figure 3). From these findings, he was diagnosed with Fechtner syndrome, a MYH9 disorder. Hypertension and additional risk factors of renal failure had been managed mainly with dietary intervention. Even at 5 years after the diagnosis, his creatinine level remained at $1.3 \mathrm{mg} / \mathrm{dL}$.

The institutional review boards of Sumitomo Hospital and Nagoya Medical Center approved this study. Written informed consent was obtained from all the patients in accordance with the principles of the Declaration of Helsinki. 
May Giemsa stain

Platelets

$(\times 1000)$
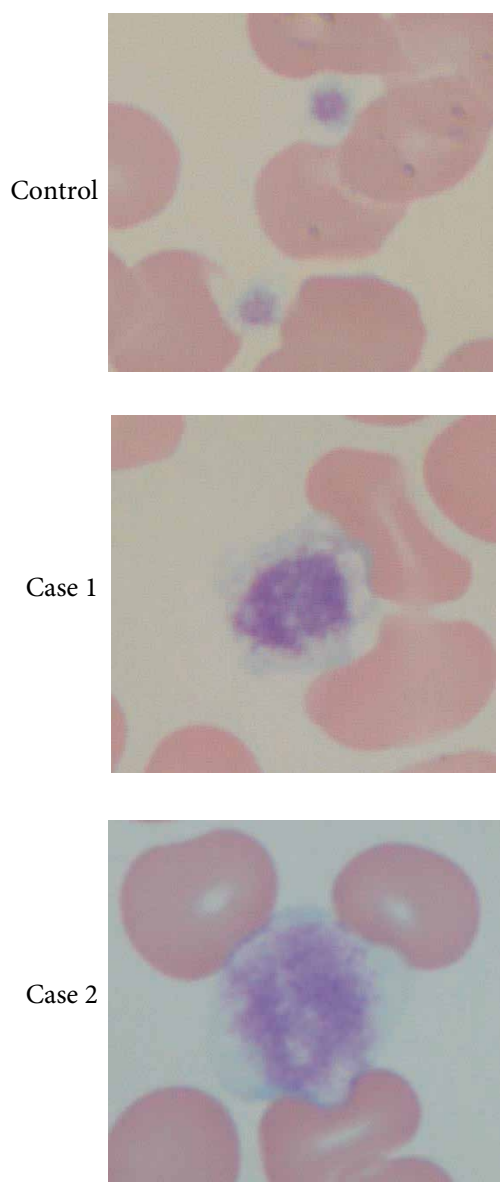

Neutrophils $(\times 1000)$

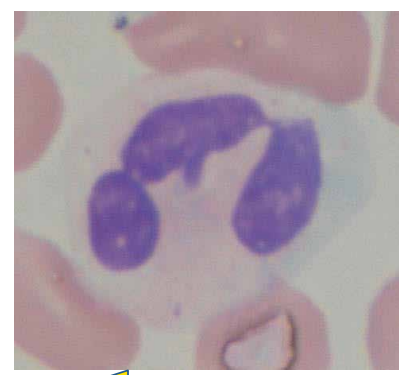

5
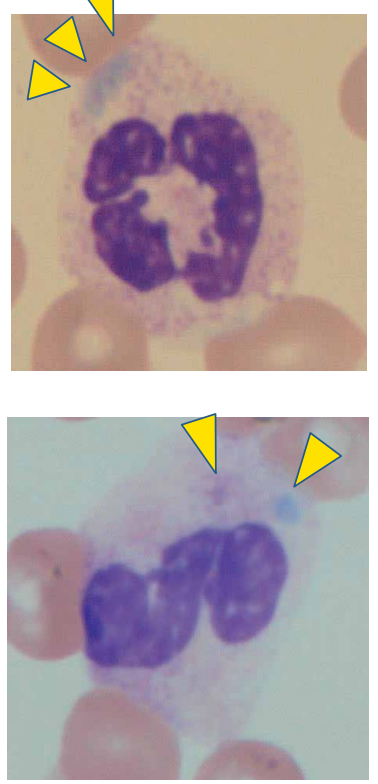

NMMHC-П A
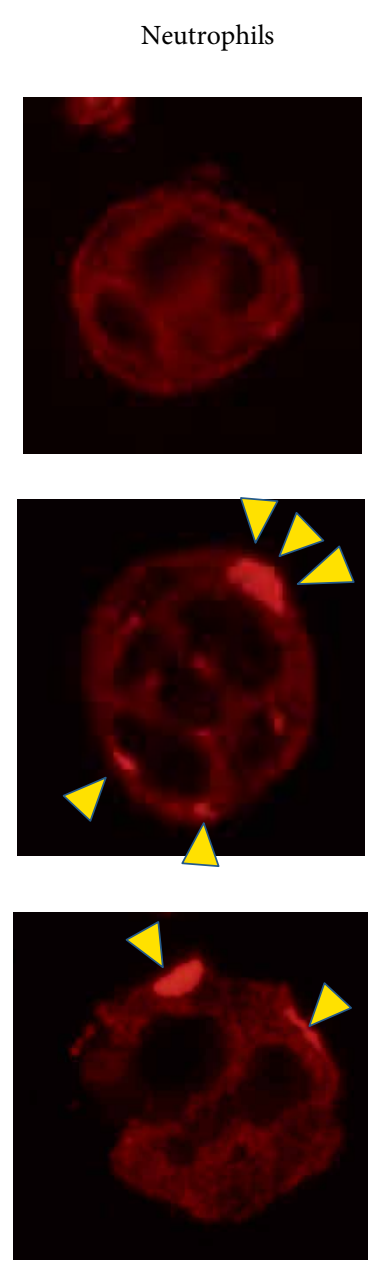

FIGURE 1: Upper panels present the control samples; middle panels, case 1 samples; and lower panels, case 2 samples. The May-Giemsa-stained platelets (in the left: original magnification $\times 1000$ ) show giant platelets from the case 1 and 2 samples. In the May-Giemsa-stained neutrophils (in the middle: original magnification $\times 1000$ ), the cytoplasmic inclusion bodies (Döhle-like bodies) in the case 1 and case 2 samples are indicated with arrowheads. The nonmuscle myosin heavy chain-II A (NMMHC-II A) distribution in neutrophils is shown in the immunofluorescence micrographs of the neutrophils (in the right). NMMHC-II A is diffusely distributed in the control neutrophils. Arrowheads represent the accumulation of granular NMMHC-II A in neutrophils of cases 1 and 2.

\section{Discussion}

MYH9 disorders include May-Hegglin anomaly, Sebastian syndrome, Fechtner syndrome, and Epstein syndrome. These are classified according to the presence of giant platelets, granulocyte inclusion bodies (Döhle-like bodies), nephritis, sensorineural deafness, and cataract [1-3] (Table 2). Here, we describe two cases of Fechtner syndrome before end-stage renal failure. In case 1, a large amount of proteinuria was observed. Owing to renal atrophy, we did not perform a renal biopsy. In contrast, in case 2 , mild proteinuria was observed. However, electron microscopy revealed focal and segmental effacement of podocytes and loss of the interpodocyte slit diaphragm. The MYH9 gene encodes the nonmuscle myosin heavy chain -IIA (NMMHC-IIA). NMMHC-II A is an actin-binding protein that also plays an important role in cell adhesion and maintenance of tissue architecture [4]. It forms myosin II A with myosin light chain and is responsible for the contractile mechanism in the foot process of podocytes [5]. In previous studies, these changes were reported to be associated with the loss of NMMHC-II A expression [6]. This falling out of the foot process is responsible for proteinuria [7]. In many previous reports of $\mathrm{MYH} 9$ disorders, cases of Fechtner syndrome complicated with renal failure were diagnosed after end-stage renal failure $[8,9]$. Here, our two cases could be diagnosed before end-stage renal failure on the basis of the main findings, including giant platelets and granulocyte inclusion bodies (Döhle-like bodies). As an advantage of diagnosis before end-stage renal failure, erroneous treatment such as immunosuppressive therapy can be prevented. In addition, antihypertensive therapy can be started early, as done in our cases. In previous studies, administration of an angiotensin II receptor blocker or an angiotensin-converting enzyme inhibitor for renal injury associated with $\mathrm{MYH9}$ disorders was 


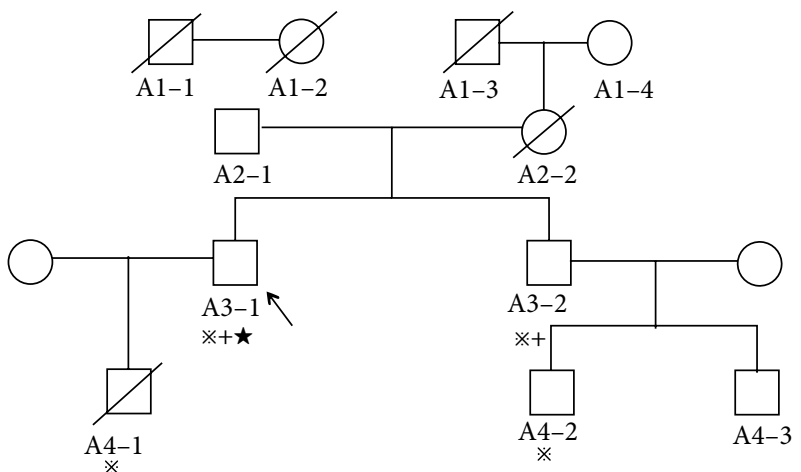

(a)

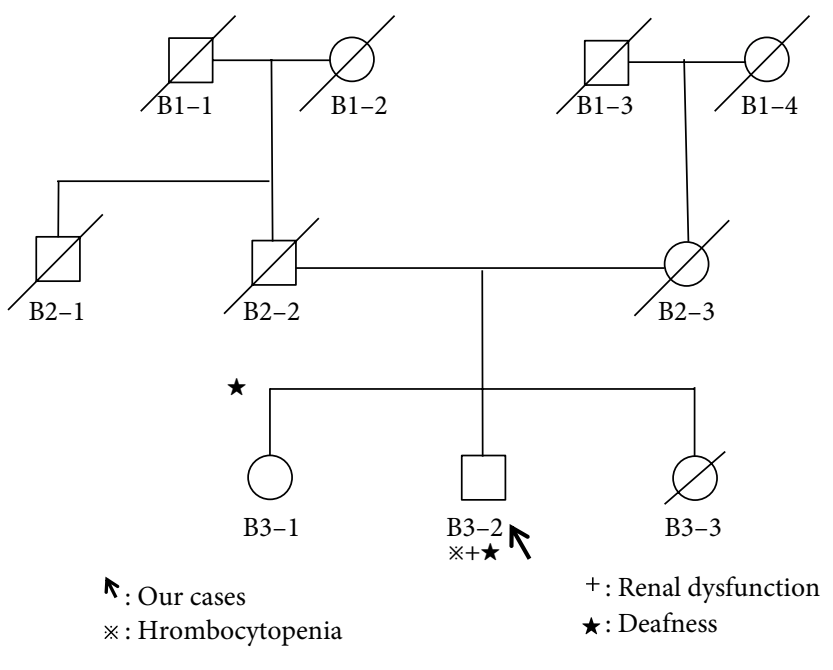

(b)

FIGURE 2: Family pedigree of our cases and sequence electropherogram of the complementary strand of the MYH9 gene. (a: case 1) Family pedigree of case 1: A1-1 died of tuberculosis at 40 years old. A1-2 died of senility at 90 years old. A1-3 died of gastric cancer at 60 years old. A1-4 had blindness and died of senility at 80 years old. A2-1 had diabetes and was 87 years old. A2-2 died of subarachnoid hemorrhage at 61 years old. A3-1 was case 1. A3-2 was 56 years old. He had thrombocytopenia and renal dysfunction. A4-1 had thrombocytopenia. He died of colon cancer at 29 years old. A4-2 had thrombocytopenia. He was 24 years old. A4-3 had no significant findings. He was 22 years old. (b: case 2) Family pedigree of case 2. B1-1, B1-2, and B1-3 died from senility at around 80 years old. B1-4 died at 60 years old. The cause of her death was unclear. B2-1 died at 62 years old. The cause of his death was unclear. B2-2 had hearing loss. He died of cerebral infarction at 84 years old. B2-3 had hypertension and died from senility at 90 years old. B3-1 was 65 years old. He had no significant findings. B3-2 was case 2. B3-3 had a gallstone. He was 62 years old.

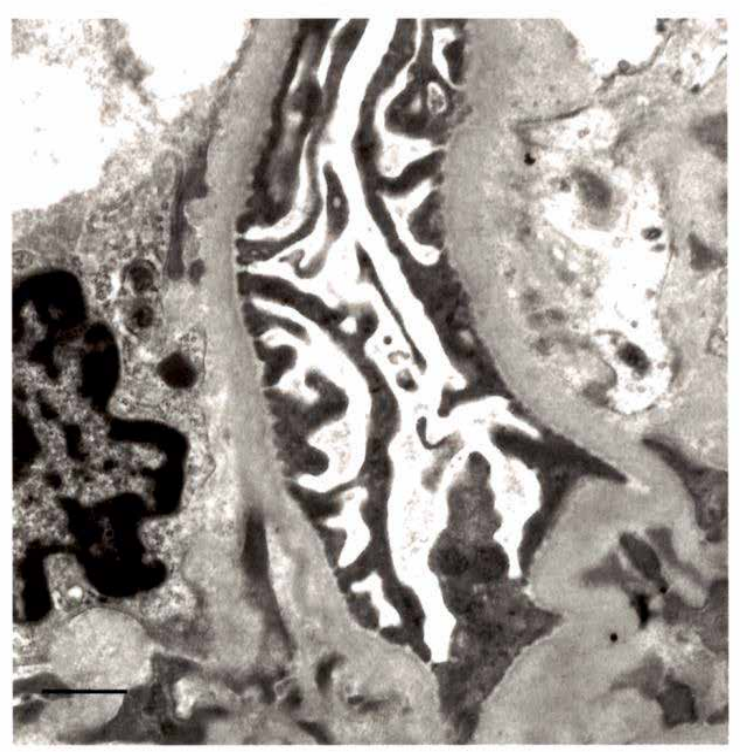

(a)

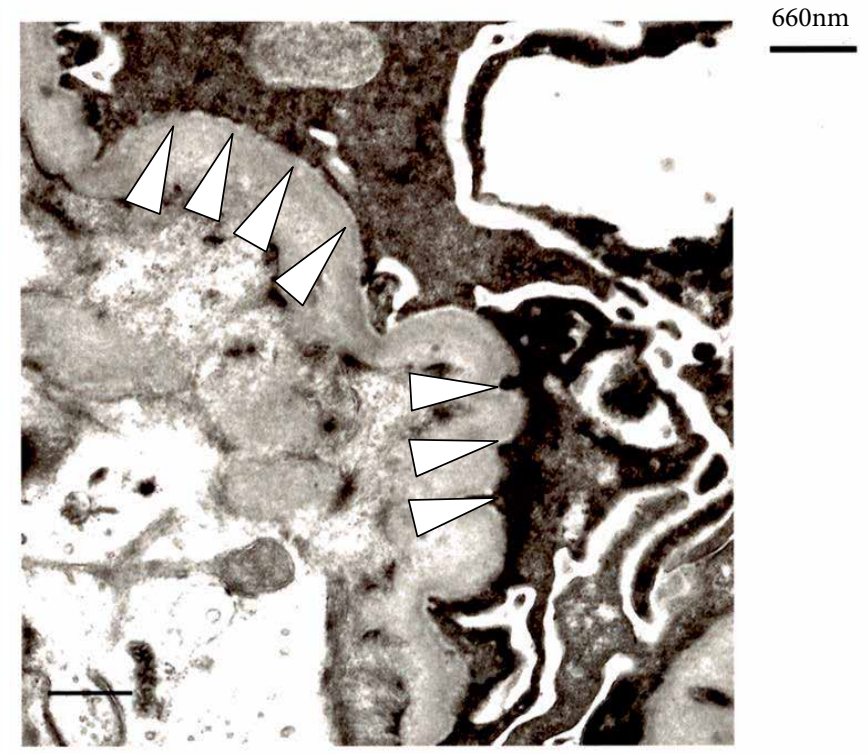

(b)

FIGURE 3: Electron microscopy image of a renal history obtained by percutaneous needle biopsy from case 2 (original magnification $\times 12000$ ). Normal podocytes and a slit diaphragm are shown (a). In the other field, focal effacement of podocytes and loss of the interpodocyte slit diaphragm are indicated by arrowheads (b).

identified to be effective to reduce proteinuria and suppress the development of renal dysfunction [10]. Diagnosis before end-stage renal failure is necessary for the management around the perioperative period, such as hemostasis during maintenance hemodialysis or tube insertion for peritoneal dialysis. Finally, because MYH9 disorders are genetic diseases, early detection of patients based on family history is also important. We can offer a genetic consultation to patients' families and other relatives. In fact, in the younger brother of case 1 , therapeutic intervention started to suppress the 
TABLE 2: MYH9 disorders; May-Hegglin syndrome, Sebastian syndrome, Epstein syndrome and Fechtner syndrome and clinical features. Clinical features of our cases and previous reported cases with the same mutations of the MYH9 gene in exon 24 .

\begin{tabular}{|c|c|c|c|c|c|c|}
\hline MYH9 disorders & & Giant platelets & $\begin{array}{c}\text { Granulocyte } \\
\text { inclusion bodies }\end{array}$ & Nephritis & $\begin{array}{c}\text { Sensorineural } \\
\text { deafness }\end{array}$ & Cataract \\
\hline May-Hegglin syndrome & & + & + (large $)$ & - & - & - \\
\hline Sebastian syndrome & & + & $+($ small $)$ & - & - & - \\
\hline Epstein syndrome & & + & - & + & + & - \\
\hline Fechtner syndrome & & + & + & + & + & + \\
\hline MYH9 gene mutations & $\begin{array}{c}\text { Age } \\
\text { and sex }\end{array}$ & $\begin{array}{c}\text { Giant platelets and } \\
\text { platelet count } \\
\text { (reference range: } \\
15.0-35.0 \times 10^{4} / \mu \mathrm{L} \text { ) }\end{array}$ & $\begin{array}{c}\text { Granulocyte } \\
\text { inclusion bodies }\end{array}$ & Nephritis & $\begin{array}{l}\text { Sensorineural } \\
\text { deafness }\end{array}$ & Cataract \\
\hline $\begin{array}{l}\text { Case 1 } \\
\text { p.E1066_A1072dup }\end{array}$ & $\begin{array}{c}56 \\
\text { Male }\end{array}$ & $\begin{array}{c}+ \\
\left(8.2 \times 10^{4} / \mu\right)\end{array}$ & + & + & + & + \\
\hline $\begin{array}{l}\text { N. Pujol-Moix et al. [12], } \\
\text { De Rocco D et al. [13] } \\
\text { p.E1066_A1072dup }\end{array}$ & $\begin{array}{c}50 \\
\text { Female }\end{array}$ & $\begin{array}{c}+ \\
+\left(1.7-8.3 \times 10^{4} / \mu\right)\end{array}$ & + & - & - & - \\
\hline $\begin{array}{l}\text { De Rocco D et al. [13] } \\
\text { p.E1066_A1072dup }\end{array}$ & $\begin{array}{c}23 \\
\text { Male }\end{array}$ & $\begin{array}{c}+ \\
\left(3.0-8.0 \times 10^{4} / \mu\right)\end{array}$ & + & - & - & + \\
\hline $\begin{array}{l}\text { De Rocco D et al. [13] } \\
\text { p.E1066_A1072dup }\end{array}$ & $\begin{array}{c}25 \\
\text { Female }\end{array}$ & $\begin{array}{c}+ \\
\left(3.0-8.0 \times 10^{4} / \mu\right)\end{array}$ & + & - & - & - \\
\hline $\begin{array}{l}\text { Case } 2 \\
\text { p.E1084del }\end{array}$ & $\begin{array}{c}59 \\
\text { Male }\end{array}$ & $\begin{array}{c}+ \\
\left(8.7 \times 10^{4} / \mu\right)\end{array}$ & + & + & $-\sim \pm$ & + \\
\hline $\begin{array}{l}\text { Miyazaki et al. [14] } \\
\text { p.E1084del }\end{array}$ & $\begin{array}{c}21 \\
\text { Male }\end{array}$ & $\begin{array}{c}+ \\
\left(8.5 \times 10^{4} / \mu\right)\end{array}$ & + & - & - & - \\
\hline
\end{tabular}

development of renal failure. As mentioned earlier, the diagnosis of MYH9 disorders before end-stage renal failure is meaningful; therefore, careful observation of giant platelets and Döhle-like bodies in patients with chronic kidney disease (CKD) is important. However, in Epstein syndrome, inclusion bodies are difficult to recognize in granulocytes.

Cases with MYH9 mutations in exon 24 might clearly show Döhle-like bodies and giant platelets. Previously, about 30 mutations of the MYH9 gene were reported. However, among the 40 exons in the MYH9 gene, mutations are concentrated in the specific codons of exons $1,16,26,30,38$, and 40 [11]. Both our cases had mutations in exon 24. In previous studies, cases with mutations in exon 24 were very rare [12-14]. Even among the same genetic mutations, the phenotype can vary [15]. Kidney damage occurs in approximately $25 \%$ of patients with MYH9 disorders as progressive proteinuric nephropathy. In most cases, nephropathy occurs before the age of 35 years and presents an aggressive course. In some cases, proteinuria may appear later and/or show a slower progression [16]. Hearing loss occurred in approximately $50 \%$ of cases at a mean age of 33 years [17]. As indicated in Table 2, thrombocytopenia is common, but the occurrence of symptoms such as renal disorder, deafness, and cataract differed from each other even in the same genetic mutation. These findings indicate that other factors such as age or sex might be required for the onset and progression of symptoms. Therefore, in cases with thrombocytopenia, attention should be paid to the possibility of MYH9 disorders.

There still remain many unknown points regarding the pathophysiology of MYH9 disorders, particularly Fechtner syndrome. Further investigation is required to assess the incidence and mechanism of renal failure in MYH9 disorders, especially Fechtner syndrome.

In conclusion, in patients with chronic kidney disease, findings of giant platelets and granulocyte inclusion bodies (Döhle-like bodies) are important for the diagnosis of MYH9 disorders, particularly Fechtner syndrome.

\section{Disclosure}

Shinji Kunishima, Department of Medical Technology, School of Health Sciences, Gifu University of Medical Science, Seki, Gifu, Japan.

\section{Conflicts of Interest}

The authors declare that they have no conflicts of interest.

\section{Authors' Contributions}

Shin Teshirogi and Jun Muratsu contributed equally to this work.

\section{References}

[1] S. Kunishima, T. Kojima, T. Matsushita et al., "Mutations in the NMMHC-A gene cause autosomal dominant macrothrombocytopenia with leukocyte inclusions (May- 
Hegglin anomaly/Sebastian syndrome)," Blood, vol. 97, no. 4, pp. 1147-1149, 2001.

[2] S. Kunishima, T. Matsushita, T. Kojima et al., "Identification of six novel MYH9 mutations and genotype-phenotype relationships in autosomal dominant macrothrombocytopenia with leukocyte inclusions," Journal of Human Genetics, vol. 46, no. 12, pp. 722-729, 2001.

[3] S. Kunishima, T. Matsushita, T. Kojima et al., "Immunofluorescence analysis of neutrophil nonmuscle myosin heavy chain-A in MYH9 disorders: association of subcellular localization with MYH9 mutations," Laboratory Investigation, vol. 83, no. 1, pp. 115-122, 2003.

[4] M. Vicente-Manzanares, X. Ma, R. S. Adelstein, and A. R. Horwitz, "Nonmuscle myosin II takes centre stage in cell adhesion and migration," Nature Reviews Molecular Cell Biology, vol. 10, no. 11, pp. 778-790, 2009.

[5] T. Sekine, M. Konno, S. Sasaki et al., "Patients with EpsteinFechtner syndromes owing to MYH9 R702 mutations develop progressive proteinuric renal disease," Kidney International, vol. 78, no. 2, pp. 207-214, 2010.

[6] K. Miura, H. Kurihara, S. Horita et al., "Podocyte expression of nonmuscle myosin heavy chain-IIA decreases in idiopathic nephrotic syndrome, especially in focal segmental glomerulosclerosis," Nephrology Dialysis Transplantation, vol. 28, no. 12, pp. 2993-3003, 2013.

[7] G. M. Ghiggeri, G. Caridi, U. Magrini et al., "Genetics, clinical and pathological features of glomerulonephritis associated with mutations of nonmuscle myosin IIA (Fechtner syndrome)," American Journal of Kidney Diseases, vol. 41, no. 1, pp. 95-104, 2003.

[8] R. Ishida, T. Kusaba, Y. Kirita et al., "A case of a hemodialysis patient with MYH9 disorders," Japan Journal of Nephrology, vol. 53, no. 2, pp. 195-199, 2011.

[9] J. Shibuya, A. Kiya, and T. Kuroda, "The start of hemodialysis in a patient with May-Hegglin anomaly complicated by Alportlike symptoms," Journal of Japanese Society for Dialysis Therapy, vol. 44, no. 8, pp. 689-694, 2011.

[10] A. Pecci, A. Granata, C. E. Fiore, and C. L. Balduini, "Reninangiotensin system blockade is effective in reducing proteinuria of patients with progressive nephropathy caused by $\mathrm{MYH} 9$ mutations (Fechtner-Epstein syndrome)," Nephrology Dialysis Transplantation, vol. 23, no. 8, pp. 2690-2692, 2008.

[11] S. Kunishima and H. Saito, "Advances in the understanding of MYH9 disorders," Current Opinion in Hematology, vol. 17, no. 5, pp. 405-410, 2010.

[12] N. Pujol-Moix, E. Muñiz-Diaz, M. Moreno-Torres et al., "platelet syndrome. Two new cases in a Spanish family," Annals of Hematology, vol. 62, no. 6, pp. 235-237, 1991.

[13] D. De Rocco, N. Pujol-Moix, A. Pecci et al., "Identification of the first duplication in $M Y H 9$-related disease: a hot spot for unequal crossing-over within exon 24 of the MYH9 gene," European Journal of Medical Genetics, vol. 52, no. 4, pp. 191-194, 2009.

[14] K. Miyazaki, S. Kunishima, W. Fujii, and M. Higashihara, "Identification of three in-frame deletion mutations in MYH9 disorders suggesting an important hot spot for small rearrangements in MYH9 exon 24," European Journal of Haematology, vol. 83, no. 3, pp. 230-234, 2009.

[15] A. Pecci, E. Panza, D. De Rocco et al., " $M Y H 9$ related disease: four novel mutations of the tail domain of myosin-9 correlating with a mild clinical phenotype," European Journal of Haematology, vol. 84, no. 4, pp. 291-297, 2010.
[16] K. H. Han, H. Lee, H. G. Kang et al., "Renal manifestations of patients with MYH9-related disorders," Pediatric Nephrology, vol. 26, no. 4, pp. 549-555, 2011.

[17] A. Pecci, C. Klersy, P. Gresele et al., "MYH9-related disease: a novel prognostic model to predict the clinical evolution of the disease based on genotype-phenotype correlations," Human Mutation, vol. 35, no. 2, pp. 236-247, 2014. 


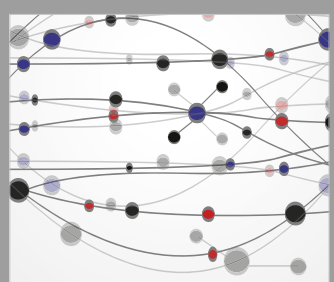

The Scientific World Journal
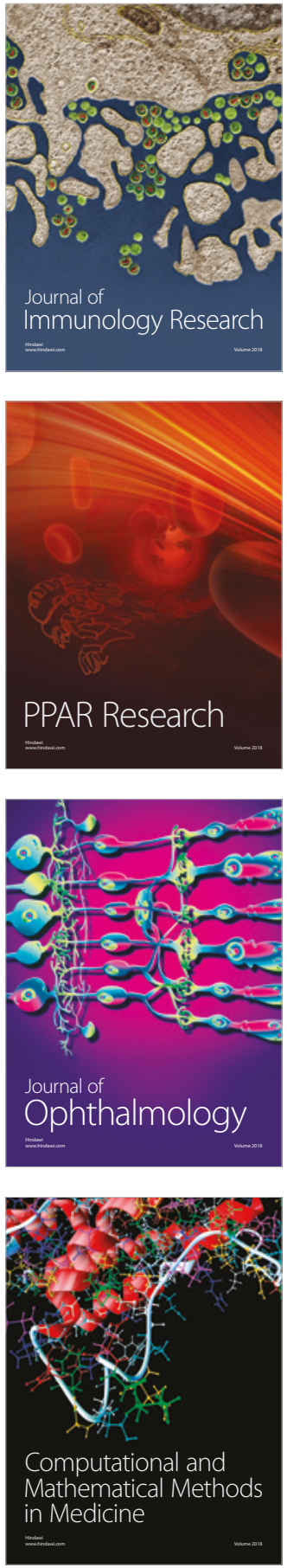

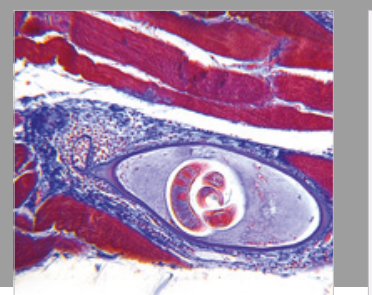

Gastroenterology Research and Practice

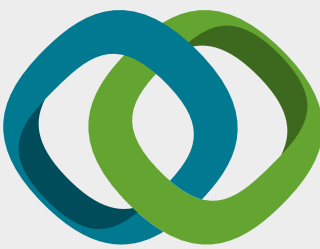

\section{Hindawi}

Submit your manuscripts at

www.hindawi.com
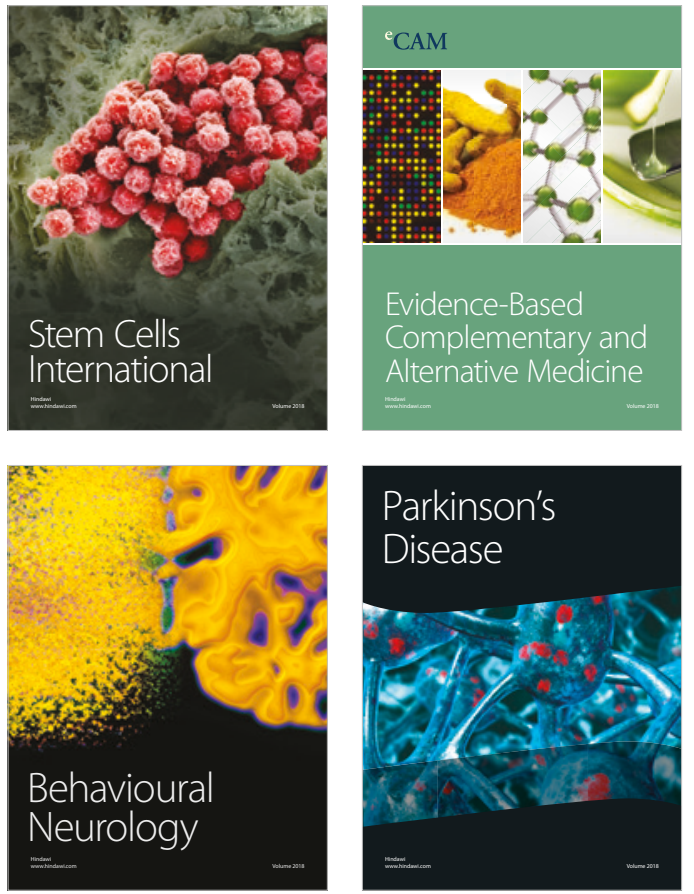

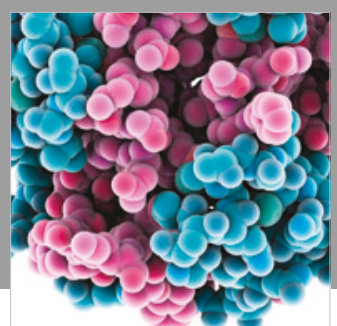

ournal of

Diabetes Research

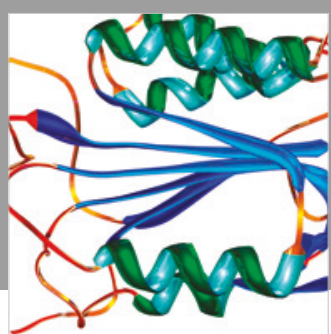

Disease Markers
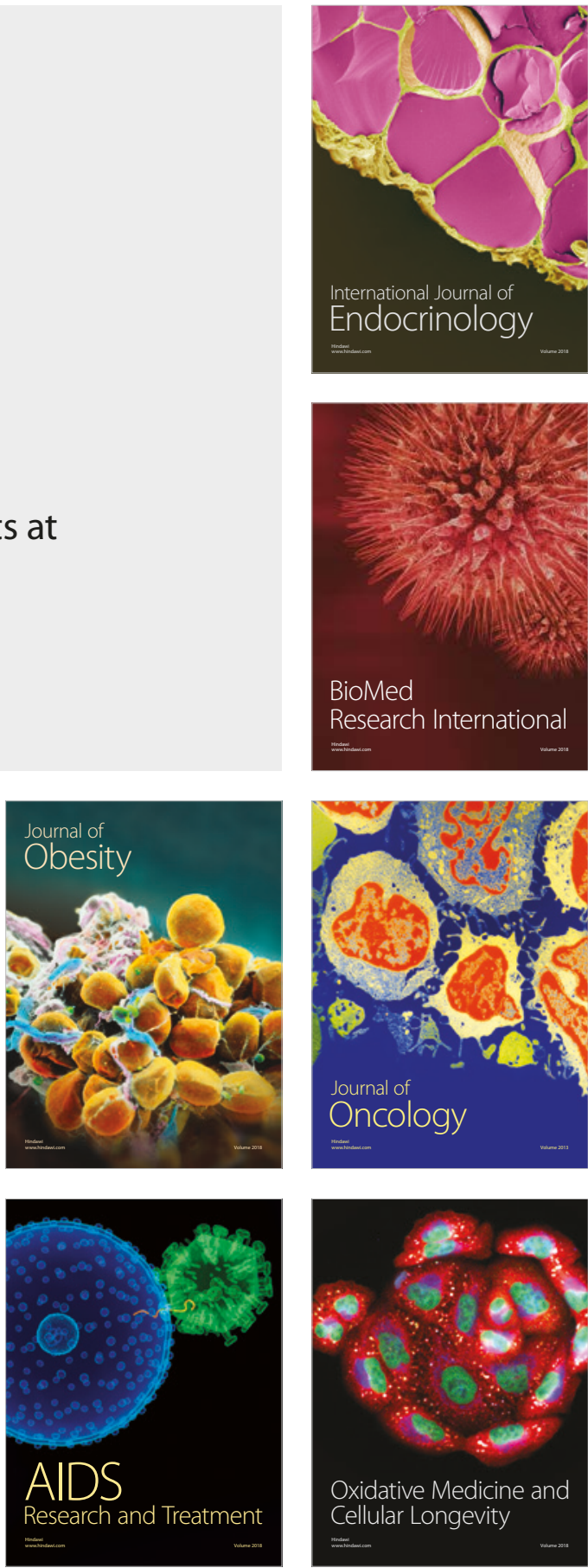